\title{
Loss of movement
}

\author{
Sophia Valesca Görgens
}

The worst part is holding still

as the machine hums around me.

On the wall are rows of heads

made of thermoplastic, masks

to guide the precision of poison

meant to kill this cancer.

I've named my cancer a dozen times

while I lie there and imagine

the silent beams of radiation.

Twenty treatments in, I grew tired

of this and named the masks instead,

hoping they could give me comfort.

Between chemo and radiation I can't decide

which I like worse, but I keep coming back-

just like my cancer, two times, now three-

to prove that I am stronger than this

malignancy. That I can hold still.

Received 25 January 2019, Accepted 12 February 2019.

Correspondence: Sophia Valesca Görgens, Emory University School of Medicine, 100 Woodruff Circle, Atlanta, GA 30322, USA. Tel: +1-404-727-6123, E-mail: sophia.gorgens@emory.edu

(c) This is an Open Access article distributed under the terms of the Creative Commons Attribution Non-Commercial License (http://creativecommons.org/ licenses/by-nc/4.0/) which permits unrestricted non-commercial use, distribution, and reproduction in any medium, provided the original work is properly cited.

www.e-roj.org 